\title{
Irregulær migrasjon - etiske, rettslige og politiske dilemmaer
}

\section{Odin Lysaker og Marit Hovdal Moan}

Dette nummeret av Etikk i praksis består av to deler, en temadel og en åpen del. Nummerets temadel dreier seg om irregulær migrasjon. Irregulære migranter skaper etiske, rettslige og politiske utfordringer for liberale velferdsstater i Europa. En irregulær migrant oppholder seg nemlig innenfor en stats grense, men er uten oppholdstillatelse. Dersom man aksepterer at stater har suveren rett til å bestemme over hvem som kvalifiserer seg til oppholdstillatelse og ikke, vil personer uten lovlig opphold reise følgende spørsmål: Har staten et ansvar for å ivareta denne gruppens sikkerhet og velferd? Det er viktig å påpeke at irregulære migranter i liberale velferdsstater ikke er fullstendig rettighetsløse. De fleste liberale velferdsstater anerkjenner at de har sivile rettigheter samt et minimum av sosiale

og økonomiske rettigheter. ${ }^{1}$ Territorielt og til en viss grad juridisk befinner de seg altså innenfor staten. Samtidig er de ekskludert fra de fleste sosiale og økonomiske rettigheter, og kan i prinsippet sendes ut av landet når som helst. På denne måten befinner de seg allikevel utenfor staten. I praksis er irregulære migranter altså på samme tid både innenfor og utenfor staten. Dette nummerets temadel inviterer til en normativ diskusjon om liberale velferdsstaters politikk overfor irregulære migranter. Og, ikke minst, hvordan samfunnet bør behandle denne gruppen innbyggere.

Andre begreper som ofte brukes om irregulære migranter, er «papirløse», «udokumenterte», «illegale» og «ulovlige» migranter. Dette er samtidig en mangefasettert gruppe, som omfatter personer med endelig avslag på egen asylsøknad, personer som ikke har oppholdstillatelse, men som av ulike grunner ikke kan returneres til hjemlandet, statsløse personer samt personer som har migrert av andre grunner enn forfølgelse i hjemlandet (slik som arbeid, studier eller familiegjenforening). Siste tall fra databasen over irregulære migranter tilhørende det europeiske forskningsprosjektet «Clandestino», anslår at det bodde mellom 1,9 og 3,8 millioner personer uten lovlig opphold i Europa i $2008 .^{2}$

Det kan tegnes et grovt kart over forskningen på irregulær migrasjon ved å plassere den innenfor et teoretisk rammeverk. Dette rammeverket kan deles inn i to akser: en vertikal og en horisontal (Fraser 2008). Den horisontale aksen er empirisk. Her plasserer vi forskning som tar for seg hvordan ulike aktører faktisk forholder seg til irregulære migranter, alt fra intrastatlige organisasjoner på lokalt plan via stater og regionale institusjoner som EU, til FN og andre globale sammenslutninger. Den vertikale aksen er normativ. På denne plasserer vi forskning som ser på hvordan ulike aktører bør behandle irregulær migranter. Videre kan det skjelnes mellom ulike posisjoner på den normative aksen langs et kontinuum fra liberal nasjonalisme til ulike former for kosmopolitisme. Liberal 
nasjonalisme tar til orde for at irregulære migranter ikke har noen rett til å oppholde seg i et ankomstland, og at denne staten ikke har noen spesielle plikter overfor personer som ikke har statsborgerskap i det aktuelle landet (Rawls 1999). Ikke desto mindre vedkjenner enkelte at også irregulære migranter kan ha et minimum av rettigheter (Miller 2007). Kosmopolitismen tar derimot til orde for ulik grad av oppmykning av staters suverenitet eller rekkevidden av deres ansvar. Videre kan denne posisjonen inndeles i tre former: moralsk (som fokuserer på menneskeverdet), rettslig (som er mest opptatt av menneskerettighetene) og politisk (som analyserer betingelsene for et globalt demokrati) (Benhabib 2004; Pogge 2002; Beitz 1979). Trass i at de ulike teoriene opererer på ulike nivåer og argumenterer på forskjellige måter, ønsker alle å bidra til en prinsipiell analyse av og debatt om migrasjonsfeltet.

Det kombinerte empiriske og normative rammeverket som vi nevnte ovenfor, er et hensiktsmessig analytisk utgangspunkt når forskningsobjektet, på grunn av sin kompleksitet, fordrer en tverrfaglig metode. Det finnes ulike former for tverrfaglig forskning. Irregulær migrasjon er et forskningsfelt som vi mener bør bedrives ut fra en empirisk informert analyse av individers og institusjoners faktiske erfaring og praksis. I tillegg reiser dette feltet grunnleggende normative spørsmål om hvordan samfunnet bør behandle dem som ikke regnes som en del av det. Slike spørsmål krever dermed en systematisk refleksjon ut fra ulike normative teorier. I dette nummeret representerer alle artiklene i temadelen en variant av dette metodiske samspillet mellom en empirisk informert analyse og en normativt orientert begrunnelse.

Temanummerets hensikt er også å bidra til en mer prinsipiell offentlig debatt om irregulær migrasjon. Etter vår oppfatning har mange av deltagerne i debatten de senere årene inntatt noen ytterpunkter. Det kan være tale om politiske eller organisasjonsmessige interesser, samt rettslige regler. Mens politiske partier eller myndighetene ofte synes å følge sine egne ideologiske interesser, følger mange jurister en regelbasert og byråkratisk standard. Også humanitære organisasjoner har en tendens til å innta ytterpunkter i debatten, siden de er ute etter å forsvare egne interessegrupper. Politikere, byråkratiet og humanitære organisasjoner vektlegger henholdsvis prinsippet om statlig suverenitet og menneskerettigheter på en måte som gjør at disse prinsippene synes å utelukke hverandre. Men innenfor rammen av en liberal velferdsstat - der det er bred enighet om at begge prinsippene skal tillegges vekt i innvandringspolitikken - er spørsmålet snarere hvordan disse hensynene bør vektes opp mot hverandre. Vi som redaktører ønsker å bidra til et normativt grunnlag for en mer prinsippbasert samfunnsdebatt rundt dette spørsmålet ved å trekke veksler på knippet av normative teorier, perspektiver og begrunnelser som de respektive artiklene tar opp. Vi har tro på at tverrfaglig forskning mellom empiriske og normative tilnærminger er av det gode. I tillegg mener vi at vekselvirkningen mellom vitenskap og politikk i betydningen et forskningsbasert og prinsipielt fundament for å vurdere politiske problemer også er å foretrekke.

Felles for artiklene i temadelen er at de inneholder en empirisk informert analyse av problemer innenfor migrasjonsfeltet. De er dermed, om enn på ulikt vis, forankret i individer eller institusjoners faktiske erfaring og praksis. Videre foreslår de normativt begrunnede forslag til løsninger på problemene de analyserer. Her trekker forfatterne veksler på 
ulike normative teorier og perspektiver - fra kosmopolitisk rettferdighetsteori via diskursanalyse og poststrukturalisme til nytteetikk. Til sammen utgjør denne kombinerte empiriske og normative tilnærmingen et relevant tverrfaglig bidrag til forskningen på irregulær migrasjon. Og til sist har alle de fire artiklene til hensikt å styrke den offentlige debatten om irregulær migrasjon med normative begrunnede prinsipper fremfor partipolitisk ideologi, frivillige organisasjoners interesser eller tendensen til rettsliggjøring av migrasjonsfeltet. Artiklene representerer imidlertid også forskjeller. Først og fremst fordi artiklene undersøker fire ulike sider av temaet irregulær migrasjon. I tillegg representerer forfatterne ulike faglige bakgrunner - fra sosiologi og sosialantropologi via internasjonale studier til teologi og filosofi.

I sin artikkel «Uten lovlig opphold = uten rettigheter? Tilværelsen til migranter uten oppholdstillatelse i lys av normativ teori om rettferdighet» tar sosiolog Katrine Fangen ved Universitetet i Oslo og sosialantropolog Halvar Andreassen Kjærre ved Cocoon ressurssenter for barnevern og etnisitet opp migrasjonsproblematikk i et rettferdighetsperspektiv. De trekker veksler på blant andre Seyla Benhabib, Hanna Arendt og Giorgio Agamben, og argumenterer for at irregulære migranter mangler en reell menneskerettighetsbeskyttelse. I den andre artikkelen, «Asylbarn og menneskeverd: Etiske refleksjoner med utgangspunkt i erfaringer fra Helsesenteret for papirløse migranter», kommer teolog Sturla Stålsett ved Kirkens Bymisjon inn på forholdet mellom migrasjon og helse. Her ser han på situasjonen for papirløse i dagens Norge, med et særlig blikk på det ulovlige helsesenteret i Oslo. Ut fra tenkere som Judith Butler og Giorgio Agamben argumenterer Stålsett for en forståelse av menneskeverdet ut fra som hvem som er berørt part i form av å kunne gråte. Den tredje artikkelen, «Papirløses rett til å søke arbeid. En konsekvensetisk vurdering», er forfattet av filosof Lars Fr. H. Svendsen ved Universitetet i Bergen. Ut fra en konsekvensetisk argumentasjon hevder han at papirløse bør ha en rett til å arbeide. Her kommer han inn på hvorvidt utlendingslovens normative begrunnelse for bestemmelsen om identitetspapirer er etisk aksepterbar eller ikke. Ifølge forfatteren bør de papirløse få anledning til å arbeide selv etter at de eventuelt har fått avslag på sin søknad om oppholdstillatelse, men fremdeles venter på å bli returnert til sitt opprinnelsesland. Den siste artikkelen, «Legitimizing policies: How policy approaches to irregular migrants are formulated and legitimized in Scandinavia», er skrevet av Martin Bak Jørgensen. Han er forsker innenfor internasjonale studier ved Aalborg universitet og bidrar med det som kan kalles et metaperspektiv på irregulær migrasjon. Bak Jørgensen gjør dette ved kritisk å analysere retorikken og forståelser av migranter som man finner i lovgivningen $i$ henholdsvis Danmark, Sverige og Norge.

Når det gjelder det rammeverket vi skisserte ovenfor, kan alle de fire artiklene hevdes å innta en form for kosmopolitisk argumentasjon. Fangen og Kjærre argumenterer ut fra en rettslig så vel som moralsk kosmopolitisme, det vil si ut fra henholdsvis menneskerettighetene og menneskeverdet. Stålsett begrunner sin posisjon på bakgrunn av en moralsk kosmopolitisme, nemlig en bestemt forståelse av menneskeverdet. Trass i at Svendsens bidrag analyserer Norges lover samt at nytteetikk i mindre grad enn for eksempel pliktetikk anvendes på transnasjonale spørsmål, inntar han en rettslig kosmopolitisme i den forstand at han hevder at irregulære migranter skal ha de samme rettighetene som enhver 
norsk borger til å kunne arbeide. Bak Jørgensens artikkel lar seg ikke like enkelt plassere innenfor vårt rammeverk, men den kan likevel leses som en type rettslig kosmopolitisme siden han tar utgangspunkt $\mathrm{i}$ irregulære migranters rettslige status ved empirisk å undersøke deres manglende rettigheter og demokratiske stemme.

I den åpne delen ser postdoktor i etikk ved Universitetet i Agder, Solveig Botnen Eide, nærmere på individuelt ansvar i lys av det hun kaller «sløvhet» innenfor profesjonsutøvelse. I hennes artikkel «Individuelt ansvar og sløvhet i profesjonsutøvelse» er Hannah Arendt inspirasjonskilden til å tenke om ansvar i komplekse byråkratier. Eide er særlig opptatt av det vanskelige eller umulige i å peke på et direkte forhold mellom individuelle handlinger og handlingers konsekvenser. Resultatet blir ofte et sterkt fokus på prosedyrer og regler. Moralsk ansvar blir videre forstått som ensbetydende med å følge regelverket. Eide, i likhet med Arendt, er kritisk til et slikt ansvarlighetsbegrep fordi det står i fare for å viske ut personen. Personen faller dermed utenfor ansvarsfeltet. Det blir irrelevant om den ansatte er et menneske som står for noe og vil noe. Moralsk sløvhet blir uansett resultatet. Det å tenke er motsatsen til denne sløvheten. De fleste av oss vil trolig kunne være enige i denne analysen. Eide skriver videre om Arendts analyse av rettsaken mot nazisten Adolph Eichmann etter andre verdenskrig. Eichmann var en person som nettopp ikke tenkte, det vil si som visket ut seg selv, og han gjorde dermed ondskapen mulig i kraft av sin moralske sløvhet. Ut fra dette perspektivet må det således reises spørsmål ved om man i det senmoderne velferdsfeltet skal og bør forvente tenkende byråkrater. For kan man ikke komme i skade for å tenke for mye i et system hvor prosedyrer og regler nettopp skal sikre rettferdighet? Eides svar på dette spørsmålet er at enhver prosedyre og regel bør testes av profesjonsutøverne selv. På bakgrunn av Eides individuelle perspektiv på det profesjonelle ansvaret består prosedyrene og reglenes robusthet nemlig i om de er prøvd med kritiske øyne.

Eides artikkel reiser spørsmål som er relevante å stille også med hensyn til statens ansvar overfor irregulære migranter. Spørsmålet om ansvarlig profesjonsutøvelse knytter an til en generell kritikk mot at normative problemstillinger skal løses ved hjelp av jusen alene. Flere av artiklene i temadelen kommer også inn på dette temaet. Eides begrep om «moralsk sløvhet» kunne således anvendes for å begrepsfeste det som omtales som rettsliggjøring og byråkratisering av statens behandling av irregulære migranter i temadelen. En annen fellesnevner er at Arendt er en sentral tenker både i Eides artikkel og i flere av artiklene i temadelen, enten i seg selv eller via Benhabib og Agamben.

\section{Noter}

1 For en oversikt over irregulære migranters rettigheter i EU, se European Union Agency for Fundamental Rights (FRA) (2011).

2 Clandestino-databasen over irregulær migrasjon i Europa ble opprettet innenfor rammen av et EUfinansierte forskningsprosjektet mellom 2007 og 2009. Databasen oppdateres med jevne mellomrom av databasens koordinatorer. For en oversikt over befolkningsanslag og metode, se http://irregularmigration.net//index.php?id=217 


\section{Litteratur}

Beitz, C.R. (1979) Political Theory and International Relations. Princeton, NJ: Princeton University Press.

Benhabib, S. (2004) The Rights of Others: Aliens, Residents, and Citizens. Cambridge: Cambridge University Press.

European Union Agency for Fundamental Rights (FRA) (2011). Fundamental rights of migrants in an irregular situation in the European Union. Lastet ned fra: http://fra.europa.eu/en/publication/2012/fundamental-rights-migrants-irregular-situation-european-union

Fraser, N. (2009) Scales of Justice: Reimagining Political Space in a Globalizing World. New York: Columbia University Press.

Miller, D. (2007) National Responsibility and Global Justice. Oxford: Oxford University Press.

Pogge, T.W. (2002) World Poverty and Human Rights: Cosmopolitan Responsibilities and Reforms. Cambridge: Polity Press.

Rawls, J. (1999) The Law of Peoples: With The Idea of Public Reason Revisited. Cambridge, MA: Harvard University Press.

\section{Gjesteredaktorer for Etikk i praksis 2/2012}

Odin Lysaker er Ph.d. i filosofi fra Universitet i Oslo. Hans doktorgradsavhandling ser på anerkjennelsen av statsløses menneskeverd. Lysaker er nå ansatt som førsteamanuensis i etikk ved Universitetet i Agder. Hans forskingsinteresser er etikk, sosialfilosofi og politisk filosofi. Lysaker har utgitt bl.a. Habermas: Kritiske lesninger (medredaktør Gunnar C. Aakvaag, Pax forlag 2007).

E-post: odin.lysaker@uia.no

Marit Hovdal Moan er Ph.d. i filosofi fra NTNU. Hennes doktorgradsavhandling tar opp spørsmålet om samfunnets plikter overfor irregulære migranter i møte med prinsippet om statlig suverenitet. Hovdal Moan jobber nå som postdoktor ved NTNU, Filosofisk Institutt, og er også tilknyttet NTNUs Program for anvendt etikk. Hennes forskningsinteresser er etikk, migrasjon, politisk filosofi samt moralsk og samfunnsmessig ansvar. Hennes siste publikasjon er "Borders as a space of interaction: An account of special state obligations to irregular immigrants» (American Behavioural Scientist, 2012, 56 (9), s. 1223-1240).

E-post: marit.hovdal.moan@ntnu.no 